\title{
Interaksi Sosial Dan Kecerdasan Moral Pada Remaja
}

\author{
Nawang Warsi Wulandari \\ Fakultas Psikologi Universitas Merdeka Malang \\ nawang.warsi@unmer.ac.id
}

\begin{abstract}
Abstrak. Tujuan penelitian ini adalah mengetahui ada tidaknya pengaruh interaksi sosial terhadap kecerdasan moral pada remaja. Subyek dalam penelitian ini adalah remaja usia SMP sebanyak 116 orang. Instrumen pengukuran yang digunakan dalam penelitian ini adalah skala kecerdasan moral dan skala interaksi sosial. Hasil uji validitas pada instrumen penelitian diperoleh data bahwa pada skala kecerdasan moral terdapat 34 aitem sahih dan pada skala interaksi sosial terdapat 28 aitem sahih. Uji reliabilitas masing-masing skala menggunakan formula Alpha Cronbach. Hasil uji reliabilitas menunjukkan bahwa skala kecerdasan moral $(0,896)$ dan skala interaksi sosial $(0,918)$ termasuk sangat reliabel. Data dalam penelitian ini dianalisis dengan menggunakan teknik regresi sederhana. Hasil analisis data diperoleh $\mathrm{F}=$ 141,884 dengan signifikasi 0,000. Hal ini menunjukkan bahwa terdapat pengaruh yang signifikan interaksi sosial terhadap kecerdasan moral. Sumbangan efektif interaksi sosial terhadap kecerdasan moral sebesar 0,554. Hal ini menunjukkan bahwa besar pengaruh interaksi sosial terhadap kecerdasan moral adalah sebesar 55,4\% sedangkan 44,6\% dipengaruhi oleh faktor lain. Hasil penelitian ini dapat digunakan sebagai pertimbangan memilih metode dalam upaya peningkatan kecerdasan moral pada remaja.
\end{abstract}

Kata kunci: interaksi sosial; kecerdasan moral; remaja

\section{Pendahuluan}

Masalah moral merupakan masalah yang sangat penting bagi setiap orang, bahkan bagi setiap bangsa. Masalah moral bangsa ini dapat mempengaruhi baik buruknya suatu bangsa. Hal ini membuat masalah moral menjadi masalah yang krusial di semua negara, termasuk Indonesia. Saat ini masalah moral menjadi masalah yang sangat menuntut perhatian berbagai pihak karena banyaknya kasus-kasus degradasi moral yang terjadi di negara ini, terutama di kalangan remaja.

Beberapa kasus krisis moral yang terjadi di Indonesia, antara lain : data KPAI menunjukkan bahwa tawuran pelajar 2018 lebih tinggi 1,1\% dibandingkan tahun lalu, terdapat 41 kasus (25,5\%) untuk kasus anak pelaku kekerasan dan bullying. Data BKKN (Badan Kependudukan dan Keluarga Berencana Nasional) menunjukkan bahwa dari 2,4 juta aborsi pada tahun 2012, dilakukan remaja usia pra nikah atau tahap SMP dan SMA. (http:/health.liputan6. com/read/2062737/sepertiga-kasus-aborsi-dilakukan-siswi-sma). Data dari BNN (Badan Narkotika Nasional) menemukan bahwa 50-60\% pengguna narkoba di Indonesia adalah kalangan remaja yakni kalangan pelajar dan mahasiswa.

Remaja sering dihadapkan pada situasi-situasi yang mengandung dilema moral. Situasi yang mengandung dilema moral menuntut remaja untuk memilih tindakan apa yang harus diambilnya. Dalam hal ini remaja akan menggunakan nilai-nilai moral yang dipahaminya dalam menentukan tindakan mana yang akan dilakukannya. Beberapa remaja dapat memilih tindakan yang benar, 
sementara beberapa remaja yang lain kurang dapat memilih tindakan yang benar. Ada kalanya remaja memahami secara moral mana perilaku yang benar dan mana yang salah, namun remaja gagal dalam berperilaku sesuai dengan pemahamannya tersebut.

Kegagalan remaja dalam memahami dan berperilaku sesuai dengan nilai moral ini menunjukkan bahwa kecerdasan moral remaja rendah. Rendahnya kecerdasan moral remaja dapat berakibat pada rusaknya moral generasi muda. Di masa yang akan datang, generasi muda sekarang yang akan memimpin bangsa. Rusaknya moral generasi muda sekarang dapat berakibat pada keruntuhan bangsa dan negara Indonesia di masa mendatang.

Kecerdasan moral adalah kemampuan untuk memahami benar dan salah dan pendirian yang kuat untuk berpikir dan berperilaku sesuai dengan nilai moral (Borba, 2001). Borba mengemukakan mengenai 7 kebajikan utama, yaitu emphaty (empati), conscience (nurani), self control (kontrol diri), respect (rasa hormat), kindness (baik budi), tolerance (toleransi) dan fairness (keadilan). Kebajikan-kebajikan utama ini akan membantu anak dalam menghadapi tantangan dan tekanan etika yang tidak bisa dihindarkan dalam kehidupannya. Kebajikan utama tersebut juga melindungi anak agar selalu berada di jalan yang benar dan membantunya untuk bertindak sesuai dengan moral. Kecerdasan moral meliputi sejumlah pengetahuan, keinginan dan penentuan dan meliputi cara berpikir, perasaan dan tindakan individu. Mengakui hanya yang benar dari yang salah dan tidak mengubah perasaan, kemampuan dan tindakan individu (Clarken, dalam Beigi dan Tabaeian, 2014).

Borba menjelaskan kecerdasan moral anak dalam tujuh aspek yang berupa kebajikan yang dimiliki seorang anak yang cerdas moral, yaitu :

\section{a. Emphaty (empati)}

Empati menunjukkan pada kepekaan pada kebutuhan dan perasaan orang lain. Empati merupakan inti emosi moral yang membantu anak memahami perasaan orang lain. Dengan empati, anak menjadi peka terhadap kebutuhan dan perasaan orang lain, mendorong anak untuk menolong yang kesusahan atau kesakitan serta memperlakukan orang dengan kasih sayang. Empati ini akan mencegah anak melakukan tindakan yang dapat menyakiti orang lain.

\section{b. Conscience (nurani)}

Nurani menunjukkan pada cenderung berani mengakui kesalahan dan mengucapkan kata maaf. Hati nurani akan membantu anak memilih jalan yang benar, tetap berada di jalur yang bermoral serta adanya perasaan bersalah saat menyimpang dari jalur yang semestinya. Hati nurani akan membentengi anak dari pengaruh buruk dan mampu bertindak benar. Hati nurani ini merupakan pondasi bagi perkembangan sifat jujur, tanggung jawab dan intergritas diri yang tinggi.

c. Self-control (kontrol diri) 
Kontrol diri menunjukkan pada kemampuan melakukan kontrol diri. Kontrol diri akan membantu anak menahan dorongan dari dalam diri anak dan berpikir sebelum bertindak. Kontrol diri akan membantu anak menjadi mandiri dalam mengendalikan tindakannya sendiri. Hal ini akan membangkitkan sikap murah dan baik hati karena anak memiliki kesadaran untuk mementingkan keperluan orang lain.

\section{d. Respect (rasa hormat)}

Rasa hormat menunjukkan pada kecenderungan dalam memperlakukan orang lain dengan penuh penghargaan meskipun berbeda. Rasa hormat mendorong anak bersikap baik dan menghormati orang lain. Rasa hormat mengarahkan anak memperlakukan orang lain sebagaimana anak ingin diperlakukan. Hal ini akan membuat anak untuk tidak bertindak kasar, tidak adil dan bersikap memusuhi. Rasa hormat ini akan membuat anak memperhatikan hak-hak serta perasaan orang lain dan menghormati dirinya sendiri.

\section{e. Kindness (baik budi)}

Baik budi menunjukkan pada kemampuan selalu menunjukkan kebaikan hati dan perhatian pada orang lain dengan contoh dari orangtua atau guru berikan. Kebaikan hati membantu anak mampu menunjukkan kepedulian terhadap kesejahteraan dan perasaan orang lain. Anak akan lebih berbelas kasih, tidak terlalu mementingkan diri sendiri dan menyadari perbuatan baik sebagai tindakan yang benar. Kebaikan hati ini membuat anak lebih memikirkan kebutuhan orang lain, menunjukkan kepedulian, memberikan bantuan pada orang yang memerlukan dan melindungi orang yang kesulitan atau kesakitan.

\section{f. Tolerance (toleran)}

Toleransi menunjukkan toleransi pada orang lain tanpa menghiraukan perbedaan. Toleransi membuat anak mampu menghargai perbedaan kualitas dalam diri orang lain, membuka diri terhadap pandangan dan keyakinan baru, menghargai orang lain tanpa membedakan. Kebajikan ini akan membuat anak memperlakukan orang lain dengan baik dan penuh pengertian, menentang permusuhan, kekejaman, kefanatikan dan menghargai orang berdasarkan karakter yang dimiliki orang lain tersebut.

\section{g. Fairness (keadilan)}

Keadilan menunjukkan pada rasa keadilan yang kuat.Keadilan menuntun anak agar memperlakukan orang lain dengan baik, tidak memihak dan adil. Hal ini membuat anak mematuhi aturan, mau bergiliran dan berbagi serta mendengar semua pihak secara terbuka sebelum memberi penilaian. Anak akan terdorong membela pihak yang diperlakukan tidak adil dan menuntut semua orang diperlakukan setara.

Salah satu faktor yang mempengaruhi perkembangan moral adalah interaksi sosial. Dikatakan oleh Turner (1988) bahwa interaksi sosial didefinisikan sebagai suatu situasi dimana perilaku seseorang secara sengaja diatur oleh orang itu dan mempengaruhi dia, orang lain dan sebaliknya. 
Pada level yang paling intens, interaksi sosial merupakan suatu proses dimana gerak-gerik terbuka, pertimbangan tersembunyi, basic physiology seseorang mempengaruhi orang lain dan sebaliknya.

Dikemukakan oleh Turner (1988) bahwa interaksi sosial memiliki beberapa elemen yaitu :

a. Motivational processes

Individu mendapatkan tenaga dan digerakkan untuk berinteraksi dengan orang lain dengan berbagai tingkatan dan dalam berbagai cara. Individu bersedia atau tidak bersedia menyimpan energi dalam saling berhubungan dengan orang lain.

\section{b. Interactional processes}

Proses ini menunjukkan apa yang terjadi saat individu mempengaruhi perilaku orang lain. Fase ini disebut Turner sebagai "mechanics" interaksi, karena hal itu melibatkan operasi kapasitas perilaku manusia yang terkontrol. Kapasitas ini melibatkan pemberian isyarat suatu tujuan perilaku dan dalam waktu yang bersamaan menginterpretasikan sinyal perilakunya sendiri dan perilaku orang lain.

\section{c. Structuring processes}

Proses ini menunjukkan bahwa interaksi sosial sering diulang

Elemen-elemen yang dikemukakan oleh Turner ini selanjutnya akan digunakan untuk menyusun instrumen pengukuran interaksi sosial dalam penelitian ini.

\section{Metode Penelitian}

Penelitian ini merupakan nonexperimental research, karena tidak memberikan perlakuan apapun terhadap variabel yang diteliti. Penelitian ini akan melakukan pengukuran dalam setting yang alami (natural) (Gall, dkk., 2003). Penelitian ini bertujuan untuk mengetahui apakah ada pengaruh interaksi sosial terhadap kecerdasan moral pada remaja. Penelitian ini juga termasuk causal relationship study. Dikemukakan oleh Gall dkk (2003) bahwa causal relationship study merupakan penelitian yang juga menjelaskan tingkat pengaruh antar variabel, selain menjelaskan hubungan antar variabel. Dengan demikian, penelitian ini menggunakan rancangan nonexperimental research dengan tipe causal relationship study.

Populasi dalam penelitian ini adalah seluruh siswa SMP Negeri 24 Malang dengan jumlah 725 siswa. Sampel dalam penelitian ini adalah siswa kelas 8 dengan jumlah 116 siswa. Teknik pengambilan sampel yang digunakan dalam penelitian ini adalah purposive random sampling. Kriteria yang harus dipenuhi oleh sampel adalah berusia 13-14 tahun dan berada di kelas 8 .

Alat ukur yang digunakan untuk mengukur kecerdasan moral adalah skala kecerdasan moral dan skala interaksi sosial. Skala kecerdasan moral yang digunakan dalam penelitian ini disusun 
oleh peneliti berdasarkan aspek-aspek kecerdasan moral dari Borba (2001). Skala interaksi sosial dalam penelitian ini disusun peneliti berdasarkan aspek-aspek interaksi sosial dari Turner (1988).

Hasil perhitungan uji validitas skala kecerdasan moral yang berjumlah 42 aitem diperoleh aitem gugur berjumlah 8 aitem. Suatu aitem dapat dikatakan valid apabila nilai korelasi $>0,300$ sedangkan suatu aitem dapat dikatakan tidak valid apabila alat tersebut mendapatkan nilai $<0,300$. Koefisien kerelasi untuk aitem-aitem valid bergerak dari 0,304 sampai 0,581 dan koefisien korelasi yang tidak valid bergerak dari 0,046 sampai 0,289. Hasil perhitungan uji validitas skala interaksi sosial yang berjumlah 30 aitem, diperoleh aitem gugur sebanyak 3 aitem. Koefisien korelasi untuk aitem-aitem yang valid bergerak dari angka 0,306 sampai 0,671, sedangkan aitem yang gugur bergerak pada angka 0,056 sampai 0,299.

Uji reliabilitas dalam penelitian untuk masing-masing skala digunakan formula Alpha Cronbach, dimana koefisien reliabilitas berada dalam rentang angka 0,00-1,00. Koefisien reliabilitas dinyatakan semakin tinggi atau semakin reliabel jika koefisien reliabilitasnya mendekati 1,00. Hasil uji reliabilitas skala kecerdasan moral diperoleh 0,896 dan skala interaksi sosial diperoleh 0,918. Hasil dari perhitungan tersebut selanjutnya disesuaikan dengan kaidah reliabilitas Guillford (Sugiyono, 2007). Berdasarkan kriteria tersebut, skala kecerdasan moral dan skala interaksi sosial termasuk sangat reliabel. Kriteria reliabilitas Guillford tersaji dalam tabel berikut ini.

Tabel 1

Kriteria Reliabilitas Guillford

\begin{tabular}{ccc}
\hline No & Interval & Kriteria \\
\hline 1. & $<2,00$ & Tidak Reliabel \\
2. & $0,200-0,399$ & Kurang Reliabel \\
3. & $0,400-0,599$ & Cukup Reliabel \\
4. & $0,600-0,799$ & Reliabel \\
5. & $0,800-1,00$ & Sangat Reliabel \\
\hline
\end{tabular}

Sebelum dilakukan analisis data, terlebih dahulu dilakukan uji asumsi. Uji asumsi untuk regresi yang digunakan dalam penelitian ini adalah uji linearitas dan uji normalitas. Uji linearitas bertujuan untuk mengetahui apakah dua variabel memiliki hubungan yang linear secara signifikan atau tidak. Data yang baik seharusnya terdapat hubungan yang linear antara variabel $\mathrm{X}$ dengan variabel Y. Uji normalitas bertujuan untuk menguji apakah data penelitia yang dilakukan memiliki distribusi yang normal. Hasil uji linearitas diperoleh $F=1,269$ dengan $p=0,188$ $(\mathrm{p}>0,05)$. Hal ini menunjukkan bahwa ada hubungan linear secara signifikan antara variabel interaksi sosial dan kecerdasan moral. Hasil uji linearitas dan normalitas dalam penelitian ini menunjukkan bahwa data dalam penelitian ini linear dan normal. Hasil perhitungan uji linearitas dan normalitas disajikan dalam tabel berikut ini.

Tabel 2 


\begin{tabular}{|c|c|c|c|c|c|c|c|}
\hline \multicolumn{8}{|c|}{ ANOVA Table } \\
\hline & & & Sum of Squares & $\mathrm{df}$ & Mean Square & $\mathrm{F}$ & Sig. \\
\hline \multirow[t]{5}{*}{$\mathrm{KM} * \mathrm{IS}$} & Between Groups & (Combined) & 16861,073 & 39 & 432,335 & 5,201 &, 000 \\
\hline & & Linearity & 12852,048 & 1 & 12852,048 & 154,618 & ,000 \\
\hline & & Deviation from Linearity & 4009,025 & 38 & 105,501 & 1,269 & , 188 \\
\hline & Within Groups & & 6317,229 & 76 & 83,121 & & \\
\hline & Total & & 23178,302 & 115 & & & \\
\hline
\end{tabular}

Hasil Uji Linearitas

Tabel 3

Hasil Uji Normalitas Kolmogorov-Smirnov

One-Sample Kolmogorov-Smirnov Test

\begin{tabular}{|c|c|c|}
\hline & & $\begin{array}{c}\text { Unstandardized } \\
\text { Residual } \\
\end{array}$ \\
\hline $\mathrm{N}$ & & 116 \\
\hline \multirow[t]{2}{*}{ Normal Parameters ${ }^{\mathrm{a}, \mathrm{b}}$} & Mean & ,0000000 \\
\hline & Std. Deviation & 9,47594373 \\
\hline \multirow[t]{3}{*}{ Most Extreme Differences } & Absolute & 072 \\
\hline & Positive & 072 \\
\hline & Negative &,- 061 \\
\hline Test Statistic & & 072 \\
\hline Asymp. Sig. (2-tailed) & &, $200^{\mathrm{c}, \mathrm{c}}$ \\
\hline
\end{tabular}

a. Test distribution is Normal.

b. Calculated from data.

Prosedur yang dilakukan dalam penelitian ini adalah (a) mempersiapkan alat ukur yang akan digunakan dalam penelitian ini; (b) mempersiapkan jadwal pengambilan data pada subyek penelitian yang terbagi dalam 8 kelas; (c) peneliti bertemu langsung dengan subyek penelitian sesuai dengan jadwal yang sudah ditentukan; (d) peneliti menjelaskan cara mengerjakan alat ukur yang digunakan; (c) peneliti meminta subyek penelitian untuk mengerjakan skala-skala pengukuran tersebut dengan cara memberikan tanda check list; (d) peneliti akan melakukan skoring dan tabulasi pada skala-skala pengukuran tersebut; (e) data penelitian siap untuk dianalisis.

Data dalam penelitian ini selanjutnya akan diolah dengan menggunakan teknik analisis regresi sederhana. Teknik ini digunakan karena tujuan penelitian ini adalah mengetahui adakah pengaruh variabel interaksi sosial terhadap variabel kecerdasan moral. 


\section{Hasil Penelitian}

Hasil uji regresi diperoleh $\mathrm{F}=141,884$ dengan sig $=0,000$. Hal ini menunjukkan bahwa ada pengaruh interaksi sosial terhadap kecerdasan moral. Besar pengaruhnya ditunjukkan dengan $\mathrm{R}$ Square $=0,554$. Hal ini menunjukkan bahwa pengaruh interaksi sosial terhadap kecerdasan moral sebesar 55,4\% dan selebihnya dipengaruhi oleh faktor yang lain yaitu sebesar 44,6\%. Hasil perhitungan uji regresi dan besar sumbangan efektifnya disajikan dalam tabel berikut ini.

Tabel 4

Hasil Uji Regresi

\begin{tabular}{|c|c|c|c|c|c|c|}
\hline \multicolumn{7}{|c|}{ ANOVA $^{\mathrm{a}}$} \\
\hline Mode & & Sum of Squares & $\mathrm{df}$ & Mean Square & $\mathrm{F}$ & Sig. \\
\hline \multirow[t]{3}{*}{1} & Regression & 12852,048 & 1 & 12852,048 & 141,884 &, $000^{\mathrm{b}}$ \\
\hline & Residual & 10326,254 & 114 & 90,581 & & \\
\hline & Total & 23178,302 & 115 & & & \\
\hline
\end{tabular}

a. Dependent Variable: KM

b. Predictors: (Constant), IS

Tabel 5

Besaran Sumbangan Efektif

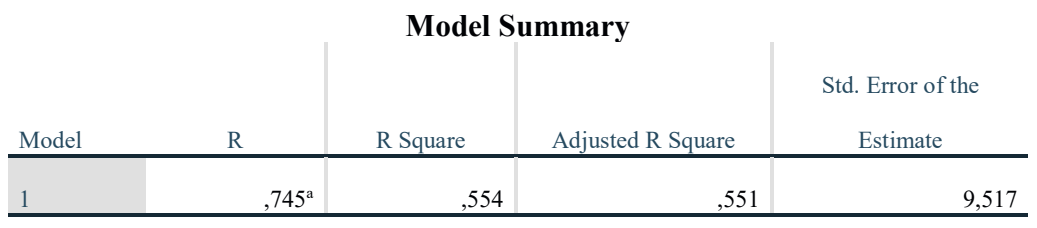

a. Predictors: (Constant), IS

\section{Diskusi}

Hasil penelitian ini menunjukkan bahwa ada pengaruh interaksi sosial terhadap kecerdasan moral. Interaksi sosial akan menyediakan banyak pengalaman bagi remaja, antara lain pengalaman dalam bekerja sama, pengalaman berkonflik bahkan pengalaman berhadapan dengan dilema moral. Kondisi ini sering memunculkan diskusi atau dialog antara remaja dengan lingkungannya. Diskusi ini dapat menstimulasi remaja dalam mengembangkan kemampuan berpikir kritisnya. Kemampuan berpikir dan diskusi yang dilakukan remaja ini akan dapat mengembangkan penalaran moralnya. Penalaran moral ini juga berkembang seiring dengan bertambahnya usia (Mason \& Gibs, dalam Bernss, 2010). Hal ini juga sesuai dengan beberapa penelitian yang percaya bahwa moral berkembang karena interaksi sosial, misalnya karena diskusi atau dialog (Walker \& Taylor; Younis, dalam Berns. 2010). 
Dalam interaksi sosial juga memungkin terjadinya proses modelling. Pihak-pihak yang dapat dijadikan model oleh remaja bisa siapa saja, di antaranya adalah orang tua, teman sebaya dan guru. Dikemukakan oleh Schunk (2012) bahwa perubahan kognitif, afektif dan perilaku dapat terjadi melalui proses modelling. Remaja akan mengamati model atau contoh yang tersaji dalam interaksi sosial tersebut. Hasil pengamatan remaja ini dapat membawa perubahan kognitif, afektif dan perilaku pada remaja. Hal ini memungkinkan terbentuknya konsep moral pada diri remaja. (Turiel, dalam Berns, 2010)

Interaksi sosial yang pertama kali terjadi adalah interaksi yang terjadi antara anak dengan orang tuanya. Keluarga merupakan tempat pertama anak belajar sesuatu, termasuk belajar tentang moral. Hal ini sesuai dengan pendapat Borba (2001) bahwa untuk membangun budaya moral harus dimulai dari rumah. Moralitas dibangun atas dasar cinta, kasih sayang dari orangtua baik ayah kepada anak maupun ibu kepada anak. Interaksi anak dengan orang lain memungkinkan adanya komunikasi yang terbuka dan dialog, anak memiliki kesempatan mengutarakan pandangan-pandangannya. Orang tua yang bersedia terlibat dalam percakapan dan mendorong anak-anaknya untuk membicarakan hal-hal yang berkaitan dengan nilai akan membuat anak-anaknya memiliki pemikiran moral yang lebih tinggi. Strategi pengasuhan dalam pembelajaran moral yang penting adalah berkomunikasi kepada anak mengenai nilai yang dianggap penting oleh orang tua. Komunikasi yang terkait dengan perkembangan moral dapat bermanfaat bagi anak. (Santrock, 2012).

Dalam sebuah penelitian yang lain disimpulkan bahwa secara umum anak-anak yang bermoral cenderung memiliki orang tua yang memiliki karakteristik sebagai berikut : hangat dan sprortif, menerapkan disiplin melalui cara membujuk, memberikan peluang kepada anakanak untuk mempelajari perspektif dan perasaan orang lain, melibatkan anak-anak dalam pengambilan keputusan di dalam keluarga dan memberikan peluang bagi anak-anak untuk melakukannya juga, memberikan informasi mengenai perilaku yang diharapkan dan disertai alasannya dan mendorong penghayatan moral yang lebih bersifat internal dibandingkan eksternal. Karakteristik tersebut cenderung akan mendorong berkembangnya perhatian dan kepedulian anak terhadap orang lain dan menciptakan hubungan yang positif antara anak dan orang tua (Eisenberg dan Valiente, dalam Santrock, 2007).

Beberapa penelitian mendukung pendapat di atas, antara lain studi literatur yang dilakukan oleh Ponzetti (2005). Studi literatur ini bertujuan untuk mendorong penggunaan kebajikan etika sebagai suatu sarana pendidikan moral dalam kehidupan keluarga. Studi literatur ini menunjukkan bahwa keluarga merupakan peletak dasar pendidikan moral bagi anak sehingga anak dapat membentuk sikap dan cara hidup anak berdasarkan apa yang anak peroleh dari keluarga. 
Penelitian lain dilakukan oleh Idowu, O., Ajayi, Samson, O. (2015). Penelitian ini dilakukan pada 230 siswa SMA. Salah satu tujuan penelitian ini adalah untuk menentukan pengaruh struktur keluarga pada kecerdasan moral siswa. Hasilnya menunjukkan bahwa ada perbedaan level moral intelligence yang signifikan berdasarkan dengan siapa subyek tinggal saat ini. Subyek yang tinggal dengan ayah dan ibu secara bersama memiliki level moral intelligence yang lebih tinggi daripada subyek yang tinggal dengan ayah atau ibu saja. Dengan tinggal bersama kedua orang tua membuat anak dapat lebih berinteraksi dengan orang tua masing-masing.

Remaja juga memiliki dorongan yang kuat untuk berkumpul dengan teman sebaya. Interaksi di antara teman sebaya yang memberikan pendapat berbeda dapat meningkatkan pemahaman moral. Penalaran dan perilaku moral dapat dikembangkan saat anak memiliki kesempatan untuk berpartisipasi dalam kelompok teman sebaya. Sebagaimana dikatakan oleh Hartup (dalam Berns, 2010) bahwa interaksi dengan teman sebaya menyediakan sumber pengetahuan, nilai-nilai dan keterampilan yang berbeda dari yang disajikan oleh orang tua. Penalaran dan perilaku moral dapat dikembangkan saat anak memiliki kesempatan untuk berpartisipasi dalam kelompok teman sebaya. Remaja yang memiliki banyak sahabat dan lebih sering berpartisipasi dalam percakapan dengan teman sebaya akan memiliki penalaran moral yang lebih maju (Schonert-Reichl, dalam Berk, 2012).

Interaksi sosial yang dilakukan remaja di sekolah juga memberikan kontribusi dalam pembentukan moral remaja. Dari interaksi sosial yang terjadi di lingkungannya, siswa akan mempelajari bagaimana perilaku moral dilakukan. Aktivitas di dalam kelas juga dapat meningkatkan perkembangan moral melalui kelompok diskusi tentang masalah-masalah moral. Program pembelajaran dan para staf yang ada di sekolah dapat mempengaruhi perkembangan moral siswa (Kohlberg; Sadker \& Sadker, dalam Berns, 2010). Dalam pendidikan moral, guru merupakan model bagi siswa di sekolah. Untuk menjadi model tersebut, guru membutuhkan pengetahuan dan kompetensi untuk membantu dalam mengembangkan moralitas siswanya (Clarken, 2009).

Hasil analisis data juga menunjukkan bahwa pengaruh intekasi sosial terhadap kecerdasan moral sebesar 55,4 \%. Hal ini menunjukkan bahwa ada pengaruh faktor lain terhadap kecerdasan moral sebesar 44,6\%. Salah satu faktor yang juga dapat mempengaruhi kecerdasan moral adalah religiusitas. Religiusitas adalah keberagamaan yaitu suatu keadaan yang ada dalam diri seseorang yang mendorongnya untuk berperilaku sesuai dengan kadar ketaatannya pada agamanya (Rahmat, 2004). Paloutzian (2005) bahwa agama juga memberikan sumbangan besar bagi pembentukan standart moral bagi para penganutnya. 
Penelitian yang dilakukan oleh Reza (2013) pada 93 siswa Madrasah Aliyah menunjukkan bahwa ada hubungan yang signifikan antara religiusitas dengan moralitas remaja, artinya semakin tinggi religiusitas remaja maka semakin baik moralitasnya. Nilai koefisien korelasinya sebesar 0,775. Penelitian lain dilakukan oleh Sari (2013). Penelitian tersebut dilakukan pada sejumlah remaja usia 12-15 tahun di Pariaman. Hasil penelitian tersebut menunjukkan bahwa ada perbedaan tingkat kecerdasan moral antara remaja yang mengikuti gerakan "Kembali ke Surau" dengan remaja yang tidak mengikuti gerakan tersebut. Remaja yang mengikuti gerakan "Kembali ke Surau" memiliki tingkat kecerdasan moral lebih tinggi, yaitu sebesar 92,5\%, dibandingkan dengan remaja yang tidak mengikuti gerakan tersebut, yaitu sebesar $57,5 \%$.

\section{Simpulan}

Hasil penelitian ini adalah ada pengaruh interaksi sosial terhadap kecerdasan moral pada remaja. Interaksi sosial yang banyak dilakukan oleh remaja adalah interaksi dengan orang tua, teman sebaya dan sekolah. Melalui diskusi dan proses modelling yang terjadi dalam berinteraksi, remaja akan dapat meningkatkan kecerdasan moralnya. Besar pengaruh interaksi sosial sebesar 55,4\%. Hal ini menunjukkan bahwa selain interaksi sosial, masih ada faktorfaktor lain yang mempengaruhi kecerdasan moral sebesar 44,6\%. Salah satu faktor yang juga mempengaruhi kecerdasan moral adalah religiusitas.

\section{Daftar Pustaka}

Beigi, K.M, Tabaeian, A. 2014. Relationship between Moral Intelligence and Coping Strategies With Conflict Among Taekwondo Coaches of Iran with Demographic Characteristic. International Jurnal of Sport Studies. Vol 4 (9), 1075-1079, 2014.

Berk, E. Laura. 2012. Development Through The Lifespan. Dari Prenatal sampai Remaja. Yogyakarta : Penerbit Pustaka Pelajar

Berns, R.M. 2010. Child, Family, School, Community : Socialization and Support. Belmont : Thompson Learning, Inc.

Borba, M. 2001. Building Moral Intelligence. San Fransisco : Josey-Bass

Clarken, R.H., Moral Intelligence in the Schools. Paper presented at the annual meeting of The Michigan Academy of Sciences, Art and Letters. Wayne State University, Detroit, MI, March 20, 2009

Gall, M. D., Gall, J. P., and Borg, W. R. 2003. Educational Research: An Introduction (7th ed). Boston: A \& B Publications 
Idowu, O., Ajayi, Samson, O. 2015. Moral Intelligence : An Antidote to Examination Malpractice in Nigerian Schools. Universal Journal of Educational Research 3 (1) : 3238, 2015.

Ponzetti, Jr. J.J. 2005. The Family As Moral Center. An Evolutionary Hermeneutic of Virtue in Family Studies. Journal of Research in Character Education ; 2005 ; 3, 1 ; Proquest Professional Education.

Reza, I.F. 2013. Hubungan Antara Religiusitas Dengan Moralitas Pada Remaja Di Madrasah $\begin{array}{lllllll}\text { Aliyah. Humanitas. Jurnal. Vol X } & \text { No. } 2013\end{array}$ http://journal.uad.ac.id/index.php/HUMANITAS/article/view/335

Santrock, JW. 2007. Remaja. Jilid 1. Jakarta : Penerbit Erlangga.

Santrock, JW. 2012. Life Span Development (13st edition). Jakarta : Penerbit Erlangga

Sari, D.P. 2013. Perbedaan Kecerdasan Moral Antara Remaja Yang Mengikuti dan Remaja Yang Tidak Mengikuti Program "Gerakan Kembali Ke Surau". http://ejournal.unp.ac.id/students/index.php/psi/article/view/596/355, Vol 1, No 1

Schunk, D.H. 2012. Teori-Teori Pembelajaran : Perspektif Pendidikan. Yogyakarta : Pustaka Pelajar

Sugiyono. 2007. Metode Penelitian. Jakarta : CV. Alfa Beta

Turner, J. H. 1988. A Theory of Social Interaction. California : Stanford University Press. 